\title{
NOWA JAKOŚĆ POLSKICH GRANIC PAŃSTWOWYCH W KONTEKŚCIE INTEGROWANIA SIĘ POLSKI Z UE A PROBLEMY PRZEPŁYWU LUDZI PRZEZ GRANICE RZECZYPOSPOLITEJ POLSKIEJ I FEDERACJI ROSYJSKIEJ. WYBRANE ASPEKTY PRAWNO-EKONOMICZNE
}

\section{Uwagi wstępne}

Problem granic państwowych na ogół zawsze miał wymiar polityczny, ekonomiczny i społeczny. Tak też jest współcześnie - w dobie transformacji, integracji i globalizacji. Jest oczywistym, że zachodzące na przełomie XX i XXI wieku przemiany geopolityczne w Polsce i jej sąsiedztwie stworzyły nową rzeczywistość polityczną i społeczno-ekonomiczną. Widoczne jest to także w dziedzinie funkcjonowania granic państwowych.

Przedmiotem rozważań prezentowanych w tym opracowaniu jest więc ogólnie pojmowany graniczny ruch osobowy przez polską granicę wschodnią (i jak wskazuje jego tytuł - ze szczególnym uwzględnieniem granicy Polski z Federacją Rosyjską) w warunkach transformacji systemowej w okresie integrowania się Polski z UE. Zaprezentowano w związku z tym niektóre unormowania prawne odnoszące się do obywateli tzw. krajów trzecich na tle szerszego zagadnienia „przenikalności polskich granic państwowych” w związku z wprowadzaniem w życie tzw. „postanowień schengeńskich". W zasadzie przedział czasowy szczegółowej analizy objął lata 2000-2005/2006. W niektórych miejscach miało jednakże miejsce wykraczanie poza ten okres - do lat wcześniejszych i późniejszych. Ze zrozumiałych względów odbywało się to już bez szczegółowego wnikania w z tym związane kwestie wcześniejsze i późniejsze. Można to uznawać za uzasadnione, tym bardziej gdy zagadnieniom tym dalej rzeczywiście poświęcone są opracowania innych autorów również przewidywane do zamieszczenia w monografii z tego cyklu tematycznego. Na podstawie dostępnych danych empirycznych dokonano analizy tego zjawiska zgodnie z sugestią wynikającą z tytułu, tj. najpierw (tzw. tle ogólnym) w odniesieniu do „przenikalności polskich granic państwowych w zakresie przeptywu ludzi”, potem 
z uszczegółowieniem problemu odnoszącego się już konkretnie do przeplywu ludzi przez granice polsko-rosyjskq w momencie integrowania się Polski z UE. Oprócz aspektu prawnego znalazły tu także odzwierciedlenie niektóre (wybrane) aspekty ekonomiczne wynikające z tej problematyki. Analiza pierwszego z nich zmierzała do określenia stopnia dostosowania obowiązujących w tym badanym ("moment integrowania się Polski z UE") przedziale czasowym regulacji prawnych do potrzeb praktyki życia społeczno-gospodarczego. Tym samym można powiedzieć, że w sensie najbardziej ogólnym sprowadzała się ona do znalezienia uzasadnionej odpowiedzi na następujące pytanie: „czy nie sq one zbyt uciażliwe dla przekraczajacych te granice - obywateli państw tzw. trzecich? Z kolei aspekt ekonomiczny zasadniczo miał na celu naświetlenie gospodarczego rozrachunku (bilansu) pozytywnych i ewentualnych negatywnych skutków tej nowej jakości granic w niektórych dziedzinach życia społeczno-gospodarczego, głównie jednak w związku ze zmianami skali turystki międzynarodowej i wielkości wpływów z tego tytułu dla gospodarki Polski. Powyższe podejście poniekąd także wynikało z samego tytułu ("Przyjazna granica - niezbędnym elementem wzmacniania stosunków społeczeństw Polski i Federacji Rosyjskiej”) poświęconego temu większego opracowania zwartego (monografii). Jego częścią składową ma przecież być także to opracowanie.

\section{Dynamika ruchu osobowego na polskich granicach w warunkach praktycznego wdrażania unormowań Układu z Schengen}

Procesy transformacji polityczno-gospodarczej zachodzące w krajach Europy Środkowej i Wschodniej spowodowały, że region ten w latach 90-tych stał się unikalnym obszarem względnie wolnego przemieszczania się osób, gdzie granice polityczne stały się półotwarte dla przemieszczania się ludzi. Mieszkańcy państw ubiegających się o członkostwo we Wspólnocie Europejskiej uzyskali możliwość przemieszczania się do niej bez obowiązku posiadania wiz. ${ }^{1}$ Natomiast obywatele takich krajów, jak: Rosja, Ukraina czy Białoruś bez większych utrudnień mogli podróżować po Europie Środkowej i Wschodniej. Otwarcie granic wpisało się tym samym zasadniczo w ustanawianie dobrych wielostronnych kontaktów z sąsiadami, prowadzonych zarówno przez Polskę jak i inne kraje tego regionu. Odnosiło się to do wielu milionów zwykłych ludzi po obu stronach granicy. Miało to też niezwykle ważny wpływ, poza kwestią ekonomiczna, na przełamanie wzajemnych, historycznie zakorzenionych uprzedzeń, stereotypów i niechęci. 
Wśród innych uwarunkowań mających zasadniczy wpływ na skalę oraz dynamikę ruchu granicznego przez polską granicę państwową z poszczególnymi krajami można zaliczyć przeobrażenia ogólnopolityczne i ogólnorynkowe. W odniesieniu do granicy wschodniej spośród czynników bezpośrednich, uwzględniających uwarunkowania polityczne i ekonomiczne, które wpłynęły na tak dużą dynamikę krotności przekroczeń, należałoby zaliczyć ${ }^{2}$ :

a) liberalizowanie przepisów paszportowych w Polsce oraz w krajach sąsiednich (zarówno Europy Wschodniej, jak też Europy Zachodniej);

b) otwartość państw na wymianę handlową;

c) rozwój transportu - zwłaszcza samochodowego;

d) uprawianie turystyki handlowej przez osoby fizyczne i niewielkie podmioty gospodarcze (zwłaszcza w latach 1993-1994) - aktualnie tendencja zdecydowanie spadkowa, m.in. wskutek wyrównywania się cen;

e) konkurencyjność towarów (dobra jakość przy cenach niższych niż zachodnioeuropejskie) wytwarzanych przez niektóre gałęzie przemysłu polskiego (np. kosmetyczny, spożywczy, odzieżowy, meblarski) na rynkach wschodnich sąsiadów, połączona $\mathrm{z}$ dużym wzrostem cen artykułów konsumpcyjnych na tych rynkach (motywacja do drobnego importu z Polski);

f) wysokie cło i akcyza na używki (alkohol, papierosy) w Polsce, skłaniające do przemytu zza granicy wschodniej, zwłaszcza przez tzw. „mrówki”.

Skalę zjawiska przestrzennego przemieszczania ludzi w latach 90-tych, można przybliżyć (oczywiście w zawężonym zakresie) przez porównanie wielkości i dynamikę granicznego ruchu osobowego przez granice Polski w 1980 i po 1989 roku. O ile, w roku 1980 wszystkie granice Polski przekroczyło łącznie 38,3 mln osób, to dziesięć lat później (1990 r.) już 84,3 mln, a w 2000 r. aż 281,2 mln (przeszło 7,3 razy więcej niż dwadzieścia lat wcześniej). Ogólnie - największy przepływ ludności odbywał się przez granicę zachodnia, zaś najmniejszy przez granicę morską (w 2003 r. było to odpowiednio -72,4 mln i 4,8 mln osób). Udział wschodniej granicy w całości ruchu granicznego w 2003 roku wynosił 15,0\%, co stanowiło 26,8 mln osób. Dla porównania - w roku 1980 granicę byłego ZSRR przekroczyło zaledwie 2,7 mln osób, a w okresie zachodzących tam zmian politycznych, np. w 1990 r., już $10,9 \mathrm{mln}^{3}$.

W tym okresie dynamika osobowego ruchu granicznego z państwami zza wschodniej granicy (Rosją Litwą, Białorusią i Ukrainą) kształtowała się na zbliżo-

2 L. Sidorowicz, Ekonomiczne konsekwencje funkcjonowania granic państwowych, Białystok 2004, s.198.

3 Ibidem, s.199-200. 
nym poziomie. Największa była w latach 1990-1991.W kolejnych latach systematycznie malała - np. w 1997 r. o 10,8\%, żeby wzrosnąć do ponad 13\% w 2000 roku i obniżać się w następnych latach oraz znowu wzrastać (por. wykres 1).

\section{Wykres 1. Dynamika osobowego ruchu przez przejścia graniczne} na wschodniej granicy Polski

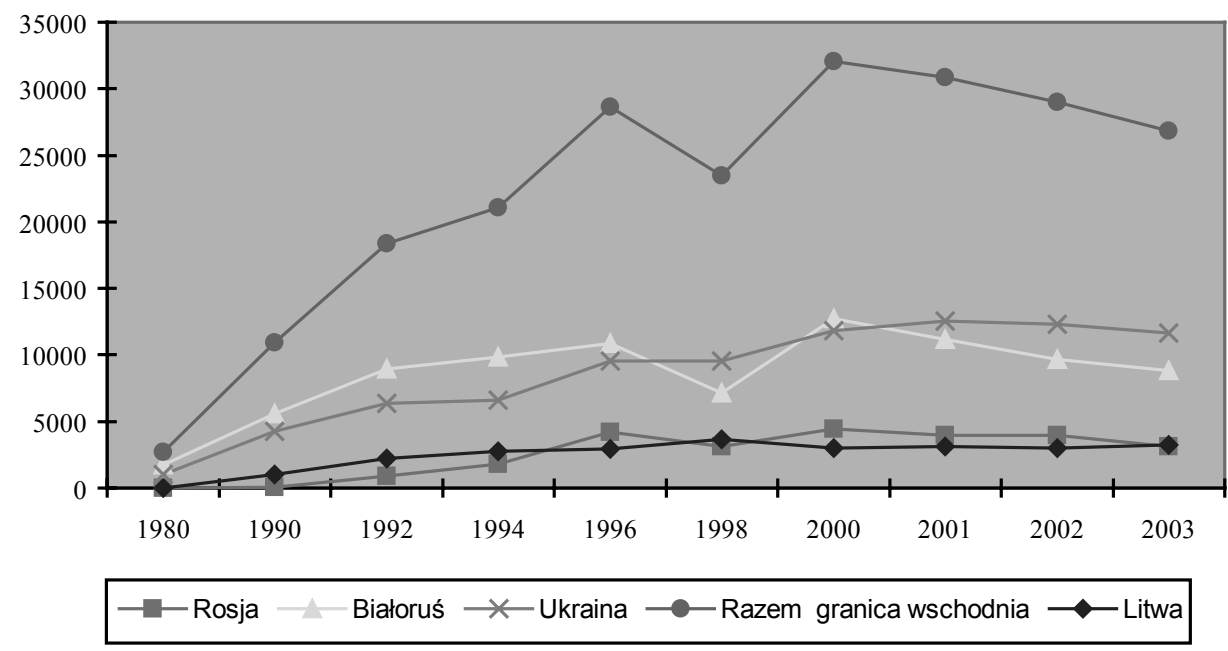

Źródło: opracowanie własne na podstawie danych Straży Granicznej.

Pierwsze załamanie dynamiki wzrostu nastapiło w latach 1992-1993. Wiązało się ono z zastąpieniem masowych przyjazdów osób sprzedających (detaliści) oraz przyjazdami kupujących (po części hurtownicy) i głównie objęło granicę ukraińską. Nie bez znaczenia były też trudności gospodarcze tego kraju. Połowa lat 90-tych to ponowne ożywienie ruchu na całej długości granicy. Ale już w 1997 r. doszło do kolejnego załamania ruchu, z Białorusią. Po części, ze względu na skomplikowaną sytuację polityczną w tym kraju, przede wszystkim jednak wskutek wprowadzenia w życie przez Polskę z dniem 1 stycznia 1998 r. nowej ustawy o cudzoziemcach, która zaostrzyła przepisy wjazdowe wobec obywateli z państw WNP. ${ }^{4}$ Skutkowało to obniżeniem przekroczeń o $18 \%$ w odniesienia do 1996 r., żeby wzrosnąć w latach następnych. I tak, na przykład, na granicy z Białorusią w 2001 r. ilość przekroczeń była o 4 mln większa w porównaniu do roku $1998^{5}$.

\footnotetext{
4 A. Maksimczuk, L. Sidorowicz, Graniczny ruch osobowy i towarowy w Unii Europejskiej, Warszawa 2007, s. 189197.

5 L. Sidorowicz, Ekonomiczne konsekwencje funkcjonowania granic państwowych, Białystok 2004, s. 201.
} 
Rok 2003 można uznać za wyjątkowy w kwestii przenikalności polskiej granicy państwowej za sprawą wprowadzenia przez nasz kraj z dniem 1 października tego roku ruchu wizowego dla obywateli Rosji, Białorusi i Ukrainy. Obietnice głoszone o otwartości granic wschodnich Polska jak dotąd dotrzymuje. Potwierdzają to dane statystyczne zjawiska osobowego ruchu granicznego i ruchu środków transportowych, pomimo faktu, że w okresie od października 2003 r. do grudnia 2004 r. liczba przyjazdów z Rosji, Białorusi i Ukrainy spadła łącznie o około $25 \%$. W kolejnych miesiącach zauważalna była niewielka tendencja wzrostowa przepływu osób z kierunku wschodniego. O otwartości granic świadczy najdobitniej ilość wydanych przez Polskę wiz. Otóż w ciaggu 15 miesięcy obowiązywania ruchu wizowego wydano aż 1,5 mln wiz, w tym dla 400 tys. obywateli Białorusi' ${ }^{6}$.

Mimo wcześniejszych obaw dotyczących wydolności systemu wydawania wiz podjęte przez stronę polską działania na rzecz jego wdrożenia okazały się skuteczne. Jak i to, że w stosunku do liczby przekroczeń granicy w okresie obowiązywania wiz odnotowano znikomą ilość przypadków odmowy wjazdu obywatelom Rosji, Białorusi i Ukrainy na terytorium Polski (7,5 tys. Rosjanom, 8,8 tys. Białorusinom, 12 tys. Ukraińcom i dla 1,2 tys. obywateli Mołdawii). Najliczniejszą grupą narodowościową której odmówiono wjazdu w 2004 roku, stanowili Filipińczycy: 17,8 tys. odmów - głównie zejść na ląd ze statków handlowych. Najczęstszym powodem odmowy przekroczenia granicy był brak wizy i środków płatniczych. Zdecydowanie najwięcej przypadków niezezwolenia na wjazd przypadło na okres bezpośrednio po wprowadzeniu nowych zasad przekraczania granicy. Również śladowy (ok. $0,15 \%$ ) był odsetek wiz unieważnionych ${ }^{7}$. Polskę odwiedziło 62 mln cudzoziemców (wzrost o 18,8\%), w tym granicę zewnętrzną przekroczyło $11 \mathrm{mln}$ obcokrajowców (spadek o 6,9\%), a wewnętrzną $51 \mathrm{mln}$ (wzrost o 26,2\%). Jeśli chodzi o obywateli polskich, to granicę przekroczyło $37 \mathrm{mln}$ rodaków (spadek o 3,9\%), w tym przez granicę zewnętrzną $6 \mathrm{mln}$ (wzrost o 11,3\%) i 31 mln przez granicę wewnętrzną, czyli spadek o $6,3 \%^{8}$.

W ciagu jednego roku obowiązywania ruchu wizowego (1 październik 2003 r. - 30 września 2004 r.) polskie urzędy konsularne na terytorium: Rosji, Białorusi i Ukrainy wydały około 1138 tys. wiz dla ok. 622 tys. Ukraińców, 300 tys. Białorusinów i 216 tys. Rosjan - jak wynika ze statystyk polskich urzędów konsularnych i statystyki KG SG w Warszawie - por. A. Maksimczuk, L. Sidorowicz, Polska granica wschodnia..., op. cit., rysunek 6. Dynamika osobowego ruchu granicznego przez przejścia graniczne z poszczególnymi państwami zza wschodnei granicy Polski, s. 87. Sytuacja na granicy państwowej w 2004 roku (porównanie do 2003 roku), KG SG, Warszawa 2005.

8 A. Maksimczuk, L. Sidorowicz, Polska granica wschodnia w warunkach transformacji (Wybrane problemy), Białystok, 2008, s. 86. 
Nowa jakość polskich granic państwowych w kontekście integrowania się Polski z UE...

Wykres 2. Krotności przekroczeń granicy państwowej RP w latach 2000-2004 (ilość paszportowych odpraw granicznych)

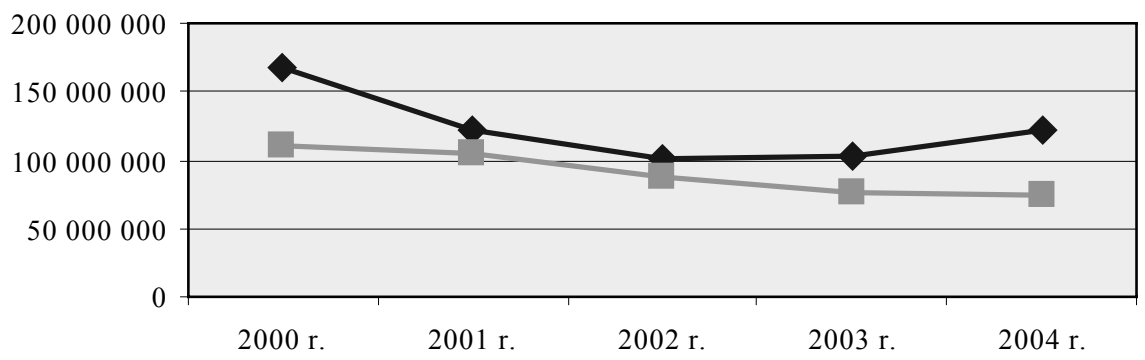

\section{$\longrightarrow$ cudzoziemcy - - Polacy}

Źródto: opracowanie własne na podstawie danych $K G S G$.

Z ogólnej ilości przekroczeń granicy zewnętrznej WE w 2004 r. zauważono zmniejszenie przyjazdów cudzoziemców do Polski o blisko 7\% - odnosząc się do poziomu z roku 2003. Mimo tego spadku tendencję wzrostową wskazuje ruch obcokrajowców przez granicę lotniczą (o 30,2\%) i na odcinku z Rosją (o 8,4\%). Natomiast spadek wystapił na granicy: morskiej (o 43,5\%), z Białorusią (o 9,1\%) i z Ukrainą (o 5,7\%). W przypadku przekroczeń odcinka zewnętrznego przez obywateli polskich zauważalny był wzrost o ponad $11 \%$ w porównaniu do roku 2003 , głównie jednak za sprawą obywateli polskich na odcinku z Obwodem Kaliningradzkim, którzy uprawiali tzw. ,handel walizkowy”, przemycając przeważnie odżywki i paliwo.

W całym 2004 r. $163 \mathrm{mln}$ osób przekroczyło wewnętrzną granicę UE. Był to wzrost o $12,2 \% \mathrm{w}$ stosunku do roku poprzedniego. Tak jak w latach poprzednich blisko połowa całego ruchu granicznego i ponad połowa ruchu granicznego cudzoziemców koncentrowała się na granicy z Niemcami. W realiach już polskiego członkostwa unijnego zauważalny był wzrost osobowego ruchu na granicy: z Niemcami (o 25,2\%), z Litwą (o 17,5\%) i ze Słowacją (o 10,2\%). Spadek miał miejsce jedynie na granicy z Czechami (o 4,6\%). Porównując do roku 2003, był on wyższy, ponad $26 \%$, co stanowiło liczbę $51 \mathrm{mln}$ osób. Miało to miejsce na wszystkich odcinkach granicy: ze Słowacją (o 37,3\%), z Niemcami (o 35,9\%), z Litwą (o 13,3\%) i z Czechami (o 6,3\%). Nastapił natomiast spadek ilości wyjazdów obywateli polskich przez granicę wewnętrzną o ponad $6 \%$. Wielkość i udział obywateli poszczególnych państw w przyjazdach do Polski uzależniona była często od tzw. „koniunk- 
tury targowiskowej”, wyrażanej na ogół korzystniejszymi relacjami cenowymi na rynkach krajów - sąsiadów ${ }^{10}$.

Widoczną konsekwencją nowego wymiaru polskiej granicy, tzn. wskutek wprowadzania unormowań schengeńskich i akcesja z UE, był niewielki wzrost przestępczości granicznej odnotowany w okresie wrzesień 2003 r. - październik 2004 r. w stosunku do analogicznego okresu 2002/2003, a także do końca 2004 r.Wzrost ten dotyczył przede wszystkim obywateli narodowości ukraińskiej (86,2\%). Najwięcej zatrzymanych za usiłowanie nielegalnego przekroczenia granicy państwowej wbrew przepisom przypadło na granicę polsko-niemiecką. Zalazło to odbicie w ilości przekazanych przez niemieckie służby graniczne, w ramach readmisji, do Polski cudzoziemców, która wzrosła o 124,9\% w stosunku do analogicznego okresu roku poprzedniego. Ogółem w 2004 roku przekazano z terytorium Polski do innych państw 6199 cudzoziemców ${ }^{11}$.

\section{Wykres 3. Natężenie ruchu osobowego na poszczególnych odcinkach granicy państwowej}

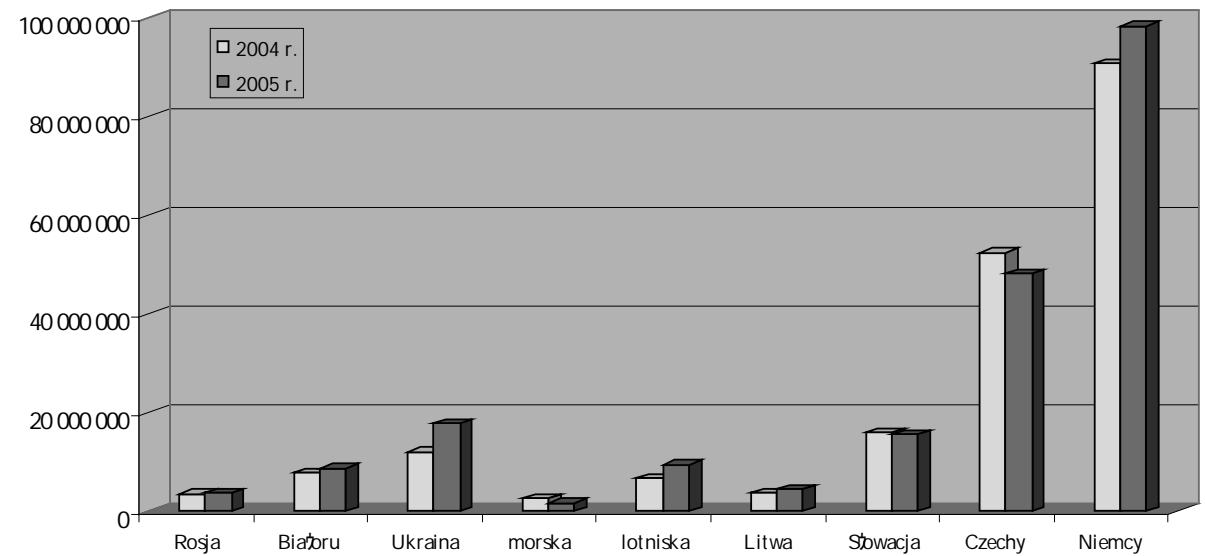

Źródło: Sytuacja na granicy państwowej w 2005 roku (porównanie do 2004 r.), KG SG, Warszawa 2006.

W związku z wjazdem do Polski Straż Graniczna dokonała 64,4 mln odpraw cudzoziemców (wzrost o 4,1\%), w tym na granicy: zewnętrznej $12 \mathrm{mln}$ (wzrost o 10,6\%), wewnętrznej 52,4 mln (wzrost o 2,7\%). Z kolei przy wyjeździe z Polski przeprowadzono 40,8 mln odpraw polskich obywateli (wzrost o 9,7\%), w tym na grani-

10 L. Sidorowicz, Zmieniający się wymiar polskiej granicy państwowej. Wybrane problemy jej przenikalności, (red.) J. Sikorski, Rozwój regionów wschodnich - szanse po przystapieniu do Unii Europejskiej, Białystok 2004, s. 350.

11 Statystyka Straży Granicznej: ruch graniczny, zwalczanie przestępczości, migracja, Warszawa 2005. 
cy: zewnętrznej $9 \mathrm{mln}$ (wzrost o 51,7\%), wewnętrznej 31,8 mln (wzrost o 1,7\%) Nierozerwalnie z granicznym ruchem osobowym wiąże się przemieszczanie się środków transportowych. W 2004 roku w ruchu drogowym przeprowadzono ponad 51 mln odpraw pojazdów (osobowych, ciężarowych i autobusów) przekraczających polską granicę z krajami członkowskimi (wzrost o 23,1\%), w tym 45 mln samochodów osobowych (wzrost o 23,4\%) oraz $6 \mathrm{mln}$ samochodów ciężarowych (wzrost o $22,2 \%$ ). Podobnie jak w ruchu osobowym, wzrost nastapił na granicy: $z$ Niemcami (38,6\%), z Litwą (o 27,1\%) i ze Słowacją (o 22,5\%). Spadek miał miejsce jedynie na granicy z Czechami (o 2\%).

W przypadku ruchu granicznego samochodów ciężarowych odnotowano wzrost na wszystkich odcinkach granicy wewnętrznej, w tym na granicy: z Litwą (o 26,2\%), z Niemcami (o 21,8\%), ze Słowacją (o 21,3\%) i z Czechami (o 20,9\%) . $^{13}$. Generalnie ożywienie na granicy wewnętrznej świadczy o zadziałaniu efektu swobodnego przepływu towarów w ramach jednolitego rynku europejskiego. Tendencja wzrostowa utrzymała się również w 2005 r. W ruchu drogowym przeprowadzono 67,9 mln granicznych odpraw pojazdów (osobowych, ciężarowych i autobusów) przekraczających granicę RP (o 11,7\% więcej niż w 2004 r.), w tym na granicy: zewnętrznej 12,2 $\mathrm{mln}$ (wzrost o 30,6\%), wewnętrznej 55,7 mln (wzrost o 8,3\%) ${ }^{14}$

Jak wynika z przedstawionych powyżej danych liczbowych zawartych w powyższej tabeli, ponad 90 \% przekroczeń granicy odbywa się przez przejścia lądowe. Sytuację tę warunkuje w znacznym stopniu kontynentalne położenie naszego kraju oraz dynamiczny rozwój transportu kołowego. Wahania dynamiki ruchu występują przeważnie przez przejścia morskie. Wyraźnie trwały dynamiczny trend wzrostowy ma miejsce w przejściach lotniczych, natomiast trend spadkowy występuje w granicznych przejściach kolejowych. Infrastruktura przejść granicznych jest istotnym czynnikiem warunkującym z jednej strony skuteczną kontrolę przekraczających osób i środków transportowych, z drugiej zaś właściwą obsługę podróżnych. Przedstawioną w opracowaniu wielkość osobowego ruchu granicznego pod koniec 2005 roku obsługiwało 272 przejścia graniczne, w tym: 194 drogowych, 33 kolejowych, 19 morskich, 6 rzecznych i 20 lotniczych. Na odcinku lądowej granicy zewnętrznej UE, tzn. z Rosją, Białorusią i Ukrainą funkcjonowało razem 31 granicznych punktów kontroli ruchu osobowego i towarowego. Jeśli chodzi o ruch na granicy wewnętrznej, to na odcinku: $z$ Litwą obsługiwały 3 przejścia graniczne, ze Słowacją55; z Czechami - 106, z Niemcami - 38, razem 202 przejścia ${ }^{15}$.

Przestępczość graniczna jest bardzo różna. Do najbardziej charakterystycznych zaliczyć należy nielegalne przekraczanie granicy państwowej. I tak dla przykładu,

Sytuacja na granicy państwowej w 2005 roku (porównanie do 2004 r.), Warszawa 2006.

Ibidem

Sytuacja na granicy państwowej w 2005 roku..., op. cit.

Sytuacja na granicy państwowej w 2004 roku (porównanie do 2003 roku), Warszawa 2005. 
w roku akcesji (2004 r.) za przekreszęnidido graniç państwowej wbrew przepisom Straż Graniczna (SG) zatrzymała ogólem 5762 osoby (wzrost o 1,8\% w stosunku do 2003 r.), w tym: na granicy zewnętrznej 1085 osób(spadek o 10,8\%), na granicy wewnętrznej 4592 osób (wzrost o 5,7\%) i w głębi kraju 85 (spadek o 14,1\%). Wśród zatrzymanych 4472 osoby byli obcokrajowcami (wzrost o 24,5\%), z tego: na granicy zewnętrznej 916 osób (wzrost o15,8\%), na granicy wewnętrznej 3475 osób (wzrost o 28,4\%). Spośród cudzoziemców zatrzymanych w 2004 r. (samodzielnie przez SG) najliczniejsi byli obywatele Ukrainy - 1884 (873 osoby w roku poprzednim) osób i odpowiednio: Rosji - 557 (w 2003 r. -310), Mołdawii - 276 (144), Chin 218 (195), Wietnamu - 146 (243), Pakistanu - 143 (161) i Białorusi - 101 (56). Zatrzymano również 133 (105) obywateli Niemiec oraz 330 (492) Czechów, jednak nie było to związane z nielegalną migracją. Wśród ogółu zatrzymanych cudzoziemców najwięcej było na granicy zewnętrznej obywatele Ukrainy stanowili - 257 (177)osób, w dalszej kolejności: Chin - 121 (78), Pakistanu - 86 (65), Rosji- 74 (34), Wietnamu - 64 (81) i Armenii - 55 (32)osób. Jeśli chodzi granicę wewnętrzna, podobnie jak na odcinku zewnętrznym wśród zatrzymanych dominowali obywatele Ukrainy - 1623 (692)osób, znaczny też był udział Rosjan- głównie jednak obywateli narodowości czeczeńskiej 475 (276) osób, a także Mołdawii - 232 (116), Chin - 95 (95) i Białorusi - 74 (45) osób ${ }^{16}$. Z kolei za przekroczenie granicy państwowej wbrew przepisom Straż Graniczna samodzielnie zatrzymała ogółem 4526 osób (spadek o 21,5\%), w tym na granicy: zewnętrznej 1384 (wzrost o 27,6\%), wewnętrznej 3007 (spadek o 34,5\%) oraz w głębi kraju 135 (w 2004 r. - 85).

\section{Wykres 4. Cudzoziemcy zatrzymani przez SG na odcinkach zewnętrznej i wewnętrznej granicy UE}
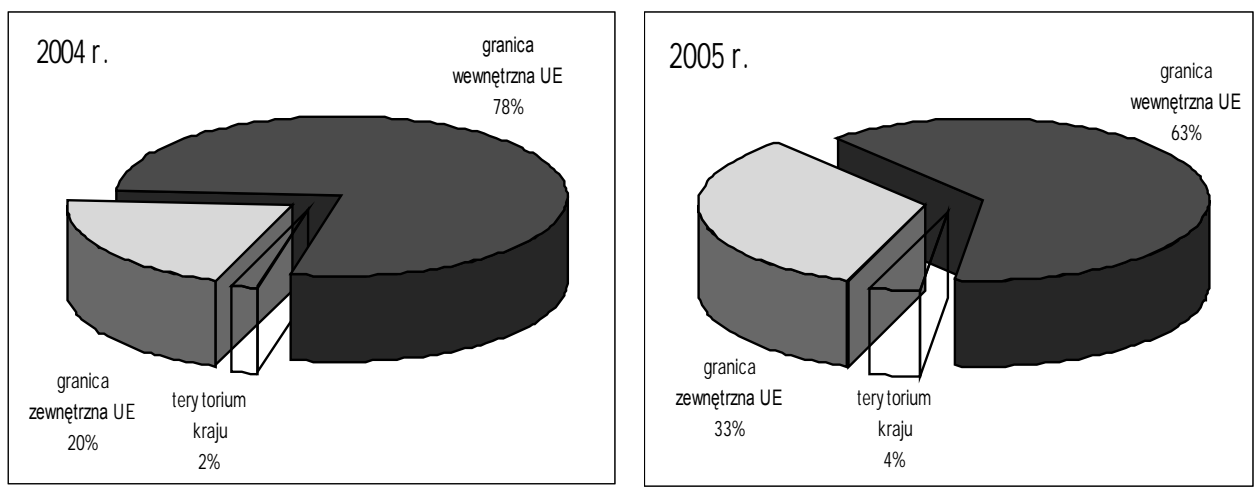

Źródło: Sytuacja na granicy państwowej..., op. cit.

W 2005 r. służby kontroli ruchu granicznego nie zezwoliły na wjazd do Polski 41663 cudzoziemcom (spadek o 36,9\%), w tym na granicy: zewnętrznej 39416 (spa- 
dek o 35,9\%), wewnętrznej 2247 (spadek o 50,6\%). Z tej ilości 31,4\% zawróconych cudzoziemców deklarowało niezgodny z rzeczywistym cel podróży, 27,6\% zawrócono z powodu braku ważnej wizy, $23,1 \%$ ze względu na brak wystarczającej ilości środków płatniczych, a $0,8 \%$ miało nieważny dokument paszportowy. Największą liczbę odmów wjazdu do RP wydano wobec obywateli: Ukrainy - 20192 (12053), Białorusi - 10548 (8821), Rosji - 4740 (7487) i Mołdawii - 2140 (1277). Należy podkreślić, że liczba odmów wjazdu wydanych cudzoziemcom z państw ryzyka migracyjnego z przyczyn związanych z nielegalną migracją wyniosła 22789 (wzrost o 22,4\%). Z tejże liczby zawrócono na granicy: zewnętrznej 22588 osób - wzrost o 22,1\% (z Ukrainą 13070 - wzrost o $65,5 \%$, z Białorusią 7348 - wzrost o 7,3\%, z Rosją 1424 - spadek o 53,1\% i na lotniczej 746 - wzrost o 4\%), wewnętrznej 201 (w 2004 r. -115$)^{17}$.

W zakresie fałszerstw dokumentów uprawniających przekraczanie granicy RP Straż Graniczna ujawniła 1995 fałszerstw dokumentów podróży lub stempli kontroli granicznej. Najczęściej fałszowano paszporty - 1024 przypadki oraz stemple kontroli granicznej - 521 przypadków. Wśród sfałszowanych paszportów najwięcej było dokumentów litewskich - 452 i polskich (głównie starego wzoru) - 269. Najczęściej fałszywe stemple kontroli granicznej ujawniano w ukraińskich dokumentach podróży - 353. W większości fałszywymi dokumentami posługiwali się obywatele: Ukrainy - 991, Polski - 196, Mołdawii - 160, Białorusi - 91 i Rosji - $88^{18}$. Zwiększyła się w 2005 r. wartość ujawnionego i zatrzymanego przez SG przemytu, wyniosła ogółem 112,7 mln zł (wzrost o 11,3\%), w tym na granicy: zewnętrznej $61,5 \mathrm{mln}$ zł (spadek o 8,5\%), wewnętrznej 29,7 mln zł (wzrost o 6,1\%) oraz w głębi kraju 21,5 mln zł (wzrost o 257,1\%) ${ }^{19}$.

Podsumowując powyższe rozważania, nasuwa się konkluzja, że współczesne funkcje granic Polski (generalnie większość granic politycznych w świecie) uległy znacznemu ograniczeniu. Ich przemiany warunkowane są w decydującej mierze procesami globalizacyjnymi (w tym integracyjnymi w Europie), demokratyzacją życia politycznego oraz coraz to większą otwartością wielu państw na wymianę gospodarczą. Mimo to zauważa się wciąż odczuwalną (zmieniającą się) rolę poszczególnych funkcji. W przypadku funkcji militarnej wiąże się to ze zdecydowanym ograniczeniem funkcji obronnej na rzecz wymiaru politycznego (przykład wschodniej granicy Polski jako fragmentu zewnętrznej granicy NATO). W aspekcie funkcji ekonomicznych kluczową rolę spełnia tu przyjęcie przez Polskę wspólnej polityki handlowej UE. Tym samym następuje zniesienie funkcji ekonomicznej na granicach z Niemcami, Czechami i Słowacją, jednocześnie uformowanie się tejże funkcji na wschodniej granicy Polski - jako zewnętrznej granicy ekonomicznej WE. Podobne przemiany od-

Ibidem, Sytuacja na granicy państwowej w 2005 roku (porównanie do 2004 r.), Warszawa 2006.

A. Maksimczuk, L. Sidorowicz, Polska granica wschodnia w okresie..., op. cit., s. 98 i dalsze.

Ibidem, s. 98-104. 
noszą się do funkcji społecznej granic naszego kraju. Zasadniczo wiążą się one z przystapieniem Polski do Układu z Schengen. Z jednej strony spowoduje to (być może już w 2007 r.) całkowitą przenikalność granicy zachodniej oraz południowej. Z drugiej zaś, wprowadzenie ruchu wizowego na wschodniej granicy powoduje, że ruch ten stał się bardziej kontrolowany w celu zapewnienia bezpieczeństwa obywatelom Państw Członkowskich i zwalczania przestępczości międzynarodowej. ${ }^{20}$

\section{Ogólna charakterystyka unormowań prawnych dotyczących przekraczania polskiej granicy wschodniej (zewnętrznej granicy UE) - ze szczególnym uwzględnieniem polsko-rosyjskiej ${ }^{21}$}

Można przyjąć, iż kształtowanie się granicy zewnętrznej Wspólnoty Europejskiej na odcinku granicy państwowej RP nastąpiło za sprawą wprowadzenia z dniem 1 października ruchu wizowego dla obywateli Rosji, Białorusi Ukrainy ${ }^{22}$ oraz daty 1 maja 2004 r., kiedy to odcinki wschodni i północny stały się fragmentem zewnętrznej granicy Wspólnoty Europejskiej. Jednocześnie oznaczało, że zniesienie kontroli na granicach wewnętrznych musi pociagać za sobą intensyfikację kontroli na granicach zewnętrznych, zwłaszcza osób niepożądanych na jej obszarze. Właśnie wymogi schengenowskie określają warunki, których spełnienie jest wymagane przy wjeździe obywateli państw trzecich na teren państw grupy Schengen. ${ }^{23}$ Jednym z kluczowych wymogów do wypełnienia w tym względzie (jak już wcześniej podkreślono), jest obowiązek wprowadzenia ruchu wizowego dla obywateli z państw trzecich, którzy nie są na tzw. „białej liście” oraz zbieranie informacji o osobach niepożądanych na obszarze Wspólnoty ${ }^{24}$. Cudzoziemca będącego obywatelem dwóch lub więcej państw traktuje się jako

Oprócz przytaczanych autorów (A. Maksimczuk, L. Sidorowicz) opracowań zwartych (monografii) o granicznej obsłudze ruchu osobowego wydanych w języku polskim, sprawy te szczegółowo prezentowane są także w monografii rosyjskojęzycznej: L. Sidorowicz, Pogranicznyj pierewoz ludiej w Eurosojuzie, Mińsk 2009.

21 W opracowaniu tym nie podejmowano próby analizy całokształtu ustawodawstwa Polski i Federacji Rosyjskiej w zakresie ruchu osobowego przez ich granice państwowe. Problemy te znajdują swoje odzwierciedlenie w innych opracowaniach, a tu skupiono się tylko na wybranych, co najwyżej niezbędnych, w związku z prezentacją problemów wynikających z jej tytułu.

22 Więcej na temat warunków przekraczania wschodniej granicy RP można znaleźć (w:) A. Maksimczuk, L. Sidorowicz, Graniczna obsługa ruchu osobowego... op. cit., s. 101-126.

23 Szerzej na temat przenikalności i ochrony granic (w:) H. Dominiczak, Granice państwa i ich ochrona na przestrzeni dziejów, Warszawa 1997 oraz T. Komornicki, Przemiany funkcji granic europejskich w XX wieku (w:) J. Kitowski, Problemy regionalnej współpracy transgranicznej, Rzeszów 1996.

24 Od 1 maja 2004 r. wobec obywateli polskich został całkowicie zniesiony obowiązek posiadania wiz przy wyjeździe do krajów Unii Europejskiej i Europejskiego Obszaru Gospodarczego - niezależnie od celu i czasu trwania pobytu. Polacy moga podróżować bez wiz do większości krajów z tzw. białej listy. Lista ta obejmuje 32 państwa, których obywatele moga wjeżdżać na terytorium Unii Europejskiej bez wiz. Zgodnie z zasadą wzajemności, kraje te nie powinny wymagać wiz od obywateli UE. Te państwa to: Andora, Argentyna, Australia, Boliwia, Brazylia, Brunei, Bułgaria, Chile, Chorwacja, Gwatemala, Honduras, Izrael, Japonia, Kanada, Korea Południowa, Kostaryka, Meksyk, Malezja, Monako, Nikaragua, Nowa Zelandia, Panama, Paragwaj, Rumunia, San Marino, Salwador, Singapur, Stany Zjednoczone, Szwajcaria, Urugwaj, Watykan i Wenezuela. „Biała lista” obejmuje też specjalne regiony pod administracją Chin: Hongkong i Makau. Z większością tych krajów Polska już zawarła umowy 
obywatela tego państwa, którego dokument podróży stanowił podstawę wjazdu na terytorium Polski. ${ }^{25}$

Przekroczenie granicy przez cudzoziemca może być uzależnione także od uiszczenia przez niego opłaty związanej z wjazdem na terytorium RP, jeżeli wymaga tego zachowanie zasady wzajemności w stosunkach $\mathrm{z}$ innymi państwami. Dlatego też z dniem 1 maja 2004 r. weszło w życie nowe rozporządzenie MSWiA z dnia 29 września 2003 r. w sprawie wysokości środków finansowych, które powinien posiadać cudzoziemiec wjeżdzajacy na terytorium Rzeczypospolitej Polskiej i dokumentów, które moga potwierdzić posiadanie tych środków oraz cel przekroczenia granicy (Dz.U. Nr 178, poz. 1748 z późn. zm.), zgodnie z którym cudzoziemiec powinien posiadać na pokrycie samych kosztów leczenia kwotę 300 zł na każdy dzień pobytu (albo jej równowartość w walutach obcych), a dokumentami mogącymi potwierdzić posiadanie przez cudzoziemca środków (z możliwościami zwolnienia z tego obowiązku w określonych przypadkach) na pokrycie ww. kosztów są: oryginał zaproszenia oraz dokument potwierdzający pokrycie tych kosztów przez ubezpieczyciela.

Lata 2003-2004 można uznać za wyjątkowe dla przenikalności polskiej granicy państwowej, w szczególności dla jej odcinka wschodniego. Przede wszystkim za sprawą wprowadzenia przez nasz kraj z dniem 1 października 2003 r. ruchu wizowego dla obywateli Rosji, Białorusi Ukrainy, co uczyniono na mocy zawartych umów bilateralnych, i tak:

a. w dniu 30 lipca 2003 roku w Kijowie podpisano Umowę między Rządem Rzeczypospolitej Polskiej a Gabinetem Ministrów Ukrainy o zasadach ruchu osobowego;

b. w dniu 26 sierpnia 2003 roku w Mińsku podpisano Umowę między Rządem Rzeczypospolitej Polskiej a Rządem Republiki Białoruś o ruchu osobowym;

c. w dniu 18 września 2003 roku w Warszawie podpisano Umowę między Rządem Rzeczypospolitej Polskiej a Rządem Federacji Rosyjskiej o warunkach podróży obywateli Rzeczypospolitej Polskie i obywateli Federacji Rosyjskiej.

o ruchu bezwizowym. Mimo że Polska zniosła obowiązek wizowy dla obywateli Australii, kraj ten nie zastosował zasady wzajemności. Także Kanada i USA nadal prezentuja sztywne stanowisko w kwestii wiz. W ramach dostosowywania polityki wizowej do wymogów UE zniesiono ruch bezwizowy między Polską a Kazachstanem (12.01.2001), Mongolia (5.05.2001), Macedonia (1.11.2002), Białorusią (1.10.2003), Rosja (1.10.2003) i Ekwadorem (10.11.2004). Wskutek wypowiedzenia umowy o wzajemnym zniesieniu obowiązku wizowego od 5 lutego 2002 r. wprowadzono ruch wizowy z Kubą. wicz, Ochrona granic i obsługa ruchu granicznego, Warszawa 2007, s. 128-142 oraz s.144-147. 
Ponadto, z dniem 1maja 2004 r. odcinki granicy RP: wschodni i północny stały się fragmentem zewnętrznej granicy Wspólnoty Europejskiej, jednocześnie odcinki granicy: południowej, zachodniej oraz z Litwą stały się granicami wewnętrznymi Państw Członkowskich WE. Nie zmieniło to jednak zasadniczo warunków przekraczania przez obywateli sąsiadujących po obu stronach polskiej granicy wschodniej i północnej.

Należy jednak podkreślić, iż zniesienie kontroli na granicach wewnętrznych musi pociagać za sobą intensyfikację kontroli na granicach zewnętrznych, zwłaszcza osób niepożądanych na jej obszarze. Wymogi schengeńskie określają bowiem warunki, których spełnienie jest wymagane przy wjeździe obywateli państw trzecich na teren grupy Schengen. Jednym z kluczowych wymogów do wypełnienia w tym względzie (jak już wcześniej podkreślono), jest obowiązek wprowadzenia ruchu wizowego dla obywateli z państw trzecich, którzy nie są na tzw. „białej liście” oraz zbieranie informacji o osobach niepożądanych na obszarze Wspólnoty. Reżim ten tworzy wymiar fragmentu zewnętrznej granicy Unii Europejskiej na odcinku polskim. Granica ta ma długość $1583 \mathrm{~km}$ : po wybrzeżu i dalej z Obwodem Kaliningradzkim (Rosją), Białorusią i Ukrainą. Można przyjąć, że kształtowanie się granicy zewnętrznej Unii Europejskiej na odcinku wschodniej granicy państwowej RP nastapiło za sprawą wprowadzenia z dniem 1 października ruchu wizowego dla obywateli Rosji, Białorusi Ukrainy. Z kolei akcesja ze Wspólnotą spowodowała formalne jej zaistnienie. Regulacje prawne określające warunki przekraczanie przez obywateli Polski i Rosji ustanowione zostały w umowie z dnia 18 września 2003 roku podpisanej miedzy Rządem Rzeczypospolitej Polskiej a Rządem Federacji Rosyjskiej o warunkach podróży obywateli Rzeczypospolitej Polskiej i obywateli Federacji Rosyjskiej. Zgodnie z treścią zapisu art.1 tejże umowy obywatele tych państw mogą wjeżdżać, wyjeżdżać, przebywać i podróżować tranzytem przez terytorium obydwóch na podstawie ważnych dokumentów stwierdzających ich tożsamość oraz wiz wydawanych przez te państwa. ${ }^{26}$

W art. 5 umowy ustanowiono warunki przemieszczania się osób obywateli obydwóch państw także w tranzycie ${ }^{27}$.

W umowie uzgodniono szereg ułatwień w przekraczaniu granicy dla znacznej ilości osób, gdyż z obowiązku posiadania wiz przewidziano też pewne zwolnienia. I tak przykładowo, nie wymaga się wiz w przypadku posiadania przez obywateli Rosji zezwolenia na zamieszkanie na czas oznaczony lub na osiedlenie się na terytorium RP, art. 8 stanowi, iż mogą oni wjeżdżać, przebywać i wyjeżdżać z teryto-

27 Postanowień niniejszego ustępu nie stosuje się wobec obywateli Polski udających się do Litwy przez terytorium Obwodu Kaliningradzkiego. 
rium Polski tylko na podstawie ważnych dokumentów stwierdzających ich tożsamość oraz kart pobytu, lecz tylko okresie ich ważności.

Mając na względzie potrzebę nieutrudniania warunków przekraczania granicy, postanowiono skrócić czas uzyskiwania wiz do niezbędnego minimum czasowego (jak to zapisano w art. 9). Z kolei w art. 10 zawarto stwierdzenie, że nw. osobom wydaje się zgodnie z prawem wewnętrznym i na podstawie przedłożenia odpowiednich dokumentów wizy uprawniające do nieograniczonej liczby wjazdów.

Należy podkreślić, iż w odniesieniu do obywateli Rosji zamieszkałych na stałe w Obwodzie Kaliningradzkim i obywateli RP zamieszkałych na stałe na terytorium Polski, Strony umowy nadały konsulom uprawnienia wydawania także bezpłatnie wiz łącznie $\mathrm{z}$ wizami uprawniającymi do nieograniczonej liczby wjazdów $\mathrm{z}$ ważnością do jednego roku, bez konieczności przedstawienia zaproszenia. W innych przypadkach wizy wydawane są odpłatnie. Wysokość opłat za wydawanie wiz przez przedstawicielstwa dyplomatyczne lub urzędy konsularne jest zazwyczaj ustalana między państwami w oparciu o zasadę wzajemności.

Jest też duża grupa osób, od których nie pobiera się opłat za wydanie wiz. ${ }^{28}$ Nieodpłatne wydawanie wiz nie dotyczy osób, które zamierzają przekroczyć granicę w celu podjęcia pracy zarobkowej. W tym przypadku tryb wydawania zezwoleń oraz wiz dla tych osób określają przepisy prawa każdego z państw (Polski i Rosji).

\section{Próba zarysowania najważniejszych problemów rozwoju turystyki przyjazdowej do Polski w warunkach „nowej jakości” polskiej granicy wschodniej}

Polska posiada wiele walorów, które mogą znacząco przyczynić się do rozwoju turystyki, w tym zagranicznej turystyki przyjazdowej. Sektor ten zajmuje w polskiej gospodarce szczególne miejsce. Należy w tym miejscu podkreślić, iż rola turystyki polega między innymi na osiaganiu takich celów strategicznych, jak: wzrost gospodarczy, stabilizacja makroekonomiczna oraz, jak zaznaczono wcześniej, ograniczenie bezrobocia. I tak na przykład szacuje się, że jedno miejsce pracy w branży turystycznej wpływa na stworzenie trzech miejsc pracy w innych branżach, tzw. „okołoturystycznych”. Warto w tym miejscu przypomnieć, że Irlandia, która postawiła na rozwój turystyki i umiejętne wykorzystała środki pomocowe UE, między innymi dzięki temu zdołała w ciągu kilkunastu lat zmniejszyć bezrobocie z 17,1\% do $3,5 \%$. Wydają się, że trafne są też opinie ekspertów zagranicznych, proponujących Polsce turystykę jako dział, który może przyśpieszyć rozwój gospodarczey ${ }^{29}$. 
Do roku 1997 liczba cudzoziemców odwiedzających Polskę systematycznie rosła. W latach 1998-2000 roku wielkość przyjazdów wahała na względnie zbliżonym poziomie, wynoszącym około $85 \mathrm{mln}$ osób przyjezdnych w ciagu roku. Wyraźny spadek zainteresowania obcokrajowców naszym krajem nastąił w 2001 roku. Został on spowodowany zmniejszeniem się liczby przyjazdów turystycznych, głównie z Niemiec oraz z niektórych krajów zachodnioeuropejskich. Trend spadkowy w latach 1997-2002 wyniósł 28,4\%. W okresie 2003-2004 mniejszy ruch graniczny charakteryzował się zmniejszeniem się liczby przyjazdów głównie obywateli Ukrainy, Białorusi i Rosji. W dużej mierze wskutek wprowadzenia z dniem 1 października 2003 roku zaostrzonego reżimu wizowego.

Wykres 5. Przyjazdy cudzoziemców do Polski w poszczególnych latach (w mln osób)

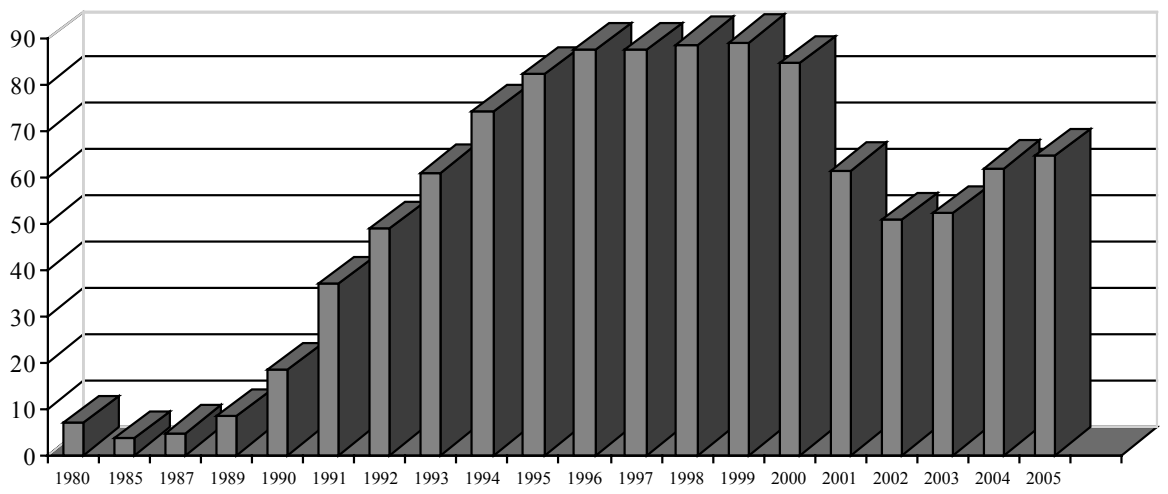

Źródło: opracowanie własne na podstawie danych Komendy Głównej Straży Granicznej.

W przyjazdach ogółem (por. wykres 5.) w badanym okresie znaczący jest wskaźnik udziału cudzoziemców zza polskiej wschodniej granicy (por. tabela 1.) - w tym głównie z Rosji. W wyrażeniu bezwzględnym, poczynając od 2000 roku, mamy do czynienia tutaj aż do 2004 roku (a w odniesieniu do Białorusi nawet do 2005 r.) z systematycznym spadkiem przyjazdów turystów z tych krajów.

Tabela 1. Przyjazdy turystów do Polski według krajów pochodzenia w poszczególnych latach (w tys. osób)

\begin{tabular}{|c|c|c|c|c|c|c|c|c|c|}
\hline Kraj & 1995 & 1997 & 1999 & 2000 & 2001 & 2002 & 2003 & 2004 & 2005 \\
\hline $\begin{array}{c}\text { Świat } \\
\text { ogółem }\end{array}$ & 19215 & 19520 & 17950 & 17400 & 15000 & 13980 & 13720 & 14290 & 15200 \\
\hline Niemcy & 6690 & 6650 & 6450 & 5920 & 4400 & 4160 & 4520 & 5230 & 5570 \\
\hline
\end{tabular}


Nowa jakość polskich granic państwowych w kontekście integrowania się Polski z UE...

\begin{tabular}{|c|c|c|c|c|c|c|c|c|c|}
\hline Rosja & 1915 & 1600 & 1160 & 1140 & 980 & 940 & 790 & 700 & 735 \\
\hline Białoruś & 2150 & 2335 & 2180 & 2370 & 2080 & 1700 & 1620 & 1460 & 1440 \\
\hline Ukraina & 3100 & 3285 & 2920 & 3090 & 3080 & 2930 & 2480 & 2340 & 2535 \\
\hline Litwa & 930 & 1100 & 960 & 850 & 840 & 840 & 825 & 815 & 830 \\
\hline Łotwa & 370 & 400 & 410 & 360 & 330 & 320 & 330 & 305 & 270 \\
\hline Estonia & 285 & 300 & 300 & 220 & 190 & 160 & 150 & 130 & 120 \\
\hline Czechy & 450 & 360 & 300 & 250 & 230 & 230 & 240 & 210 & 185 \\
\hline Słowacja & 120 & 90 & 90 & 90 & 80 & 60 & 80 & 85 & 70 \\
\hline $\begin{array}{l}\text { UE (bez } \\
\text { Niemiec) }\end{array}$ & 2030 & 2135 & 2110 & 2050 & 1805 & 1650 & 1645 & 1790 & 2015 \\
\hline $\begin{array}{c}\text { Ważne } \\
\text { zamorskie* }^{*}\end{array}$ & 260 & 310 & 330 & 360 & 340 & 310 & 330 & 400 & 505 \\
\hline WNP & 180 & 240 & 150 & 170 & 100 & 90 & 90 & 90 & 90 \\
\hline $\begin{array}{c}\text { Pozostałe } \\
\text { kraje }\end{array}$ & 735 & 715 & 590 & 530 & 545 & 590 & 620 & 735 & 835 \\
\hline
\end{tabular}

* USA, Japonia, Korea Poludniowa, Kanada, Australia.

Źródło: Opracowanie własne na podstawie danych Komendy Glównej Straży Granicznej i Instytutu Turystyki w Warszawie.

Od początku lat 90-tych ubiegłego wieku wśród przyjezdnych, w tym turystów, dominują obywatele Niemiec. Przykładowo w 2005 roku stanowili oni ponad połowę przekraczających granicę Polski (58\%), a turyści niemieccy stanowili 37\% wszystkich turystów przyjezdnych. Jeśli chodzi o innych obcokrajowców to udział ten kształtował się odpowiednio: Czech i Słowacji - 17\% i 1,1\%, razem Ukrainy, Rosji i Białorusi - 16\% i 31\%, Litwy, Łotwy i Estonii - 3\% i 8\%, obywateli z państw z UE (bez Niemiec) 4\% i 13\% oraz z pozostałych krajów 2\% i 9\% ${ }^{30}$. Większość przyjazdów cudzoziemców to krótkie (także jednodniowe) wypady do miejscowości przygranicznych po tańsze niż we własnym kraju produkty lub usługi. W 1994 roku ponad 47\% przyjazdów obywateli zza wschodniej granicy było jednodniowych, a głównym celem było dokonanie zakupów (82\%). Inne proporcje były na odcinku granicy zachodniej i południowej. W tym samym roku (1994 r.) blisko $30 \%$ wyjazdów obywateli Niemiec do Polski było typowymi wyjazdami turystycznym na okres $1-3$ dni (50\%) oraz 4-7 dni $(36 \%)^{31}$. 
Wykres 6. Pobyt cudzoziemców w Polsce w 2005 r. (wg długości noclegów)

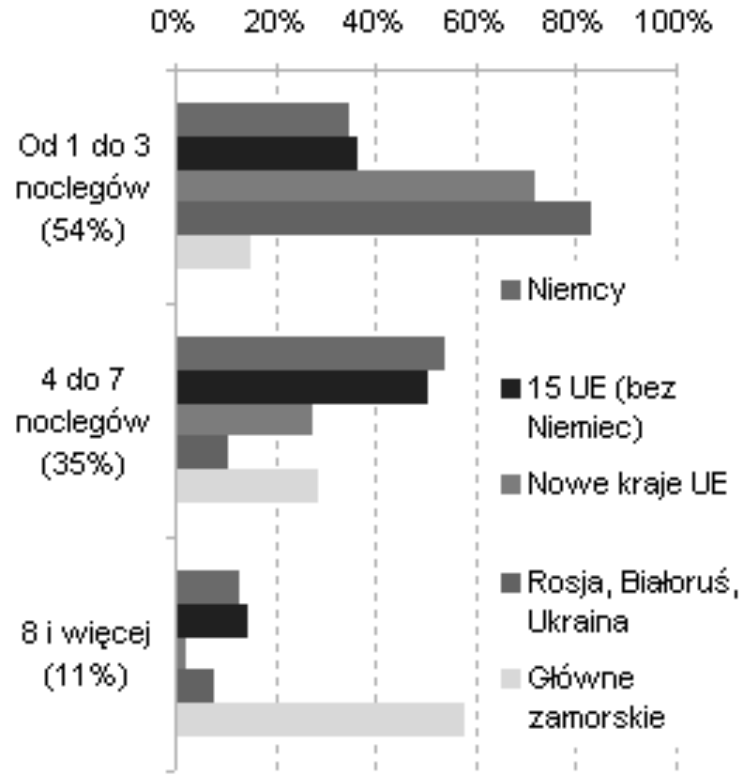

Źródło: Opracowanie własne na podstawie danych Komendy Głównej Straży Granicznej i Instytutu Turystyki w Warszawie.

Interesujące jest i to, iż około 55\% przyjazdów to były wypady 4-7 dniowe, często w weekendy. Może to tym samym stwarzać szansę rozwoju tej formy turystyki, tzn. weekendowej, w naszym kraju, która coraz częściej jest też uprawiana i przez obywateli polskich. Turyści przyjeżdżający do Polski odwiedzają głównie (w 2003 r. stanowili oni około 77\%) ośrodki miejskie, takie jak: Warszawa, Kraków, Szczecin, Gdańsk, Wrocław, Poznań, Częstochowa. Na Wybrzeże, Pomorze i Mazury przyjeżdża wielu turystów niemieckich i skandynawskich, w polskich górach wypoczywają głównie Niemcy, Holendrzy, Brytyjczycy i Francuzi. Od kilku lat zauważa się też wyraźny wzrost przyjazdów turystów rosyjskojęzycznych, zarówno w góry, jak też i w inne regiony naszego $\mathrm{kraju}^{32}$.

Warto tutaj podkreślić, że zakupy stopniowo traciły dominującą rolę w przyjazdach do Polski. W 2000 roku skończyła się dekada turystyki zakupowej. Udział przyjazdów na zakupy z Niemiec i pozostałych krajów zachodnioeuropejskich regularnie zmniejszał się. Do 2004 roku zauważało się to także w odniesieniu do sąsiadów ze wschodu. Udział przyjazdów na zakupy z Ukrainy, Rosji i Białorusi przewu osób po akcesji do Unii Europejskiej, (w:) J. Sikorski (red.), Regiony przygraniczne w warunkach zewnętrznych granic Unii Europejskiej, Białystok 2005, s. 239-243. 
kroczył 20\%, zbliżając się do poziomu z 2000 roku. Następnie, w 2005 roku, znów się obniżył do $17 \%$. Typową cechą turystyki przyjazdowej do Polski była w analizowanym okresie znaczna liczba wizyt tej samej osoby w ciagu roku. Oznacza to, że realna liczba turystów odwiedzających Polskę jest istotnie mniejsza od liczby wizyt. W 2005 roku średnia liczba wizyt w ciągu 12 miesięcy poprzedzających badanie wyniosła 3,4 na osobę, minimalnie mniej niż 2004 roku. Turyści z Rosji, Białorusi i Ukrainy przyjeżdżali średnio 5,2 razy, a 12\% spośród nich odwiedziło Polskę ponad 10-krotnie ${ }^{33}$.

Perspektywy rozwoju turystki przyjazdowej do Polski są jednak optymistyczne. Według prognoz Instytutu Turystyki średnioroczna dynamika liczby przyjazdów turystów do Polski w latach 2005-2015 wyniesie 4,5\%. Podobnego tempa wzrostu liczby przyjazdów oczekuje się z Niemiec. Zakłada się, że liczba przyjazdów turystów z Rosji, Litwy, Białorusi i Ukrainy również będzie rosła, ale w mniejszym stopniu. Istotnego wzrostu ruchu przyjazdowego można spodziewać się z nieościennych krajów U-15 (w tempie 7,4\% rocznie), Ameryki Północnej i pozostałych krajów zamorskich (10\% rocznie). Ogółem liczba przyjazdów turystów może wzrosnąc od 15,2 mln w 2005 roku do 19 mln w 2010 roku z utrzymaniem tego tempa do $2015 \mathrm{roku}^{34}$.

W okresie 2003-2013 spodziewany jest wzrost tego wskaźnika do 4,4\%. W całej Europie dochody z turystyki wyniosły 347,4 mld dol., co stanowi ok. 50,1\% światowych wpływów tego sektora. Krajem o największych dochodach z turystyki w Europie była Hiszpania (7\%) udział wpływów w turystyce światowej), na drugim miejscu znalazła się Francja (6,2\%.), a trzecie miejsce przypadło w udziale Włochom (5,2 \%). W tym samym czasie dochody z turystyki w Polsce wyniosły 6,284 mld dol. i dało to 15 . miejsce wśród państw europejskich ${ }^{35}$.

\footnotetext{
33 Cele, motywy i formy turystyki przyjazdowej do Polski w 2005 roku, Warszawa 2006, s. 4.

34 Dane Instytutu Turystyki w Warszawie

35 Wpływy z turystyki międzynarodowej w 2005 roku, Ministerstwa Gospodarki, Warszawa 2006 r.
} 
Wykres 7. Przyjazdy turystów według głównych grup krajów (w mln osób)

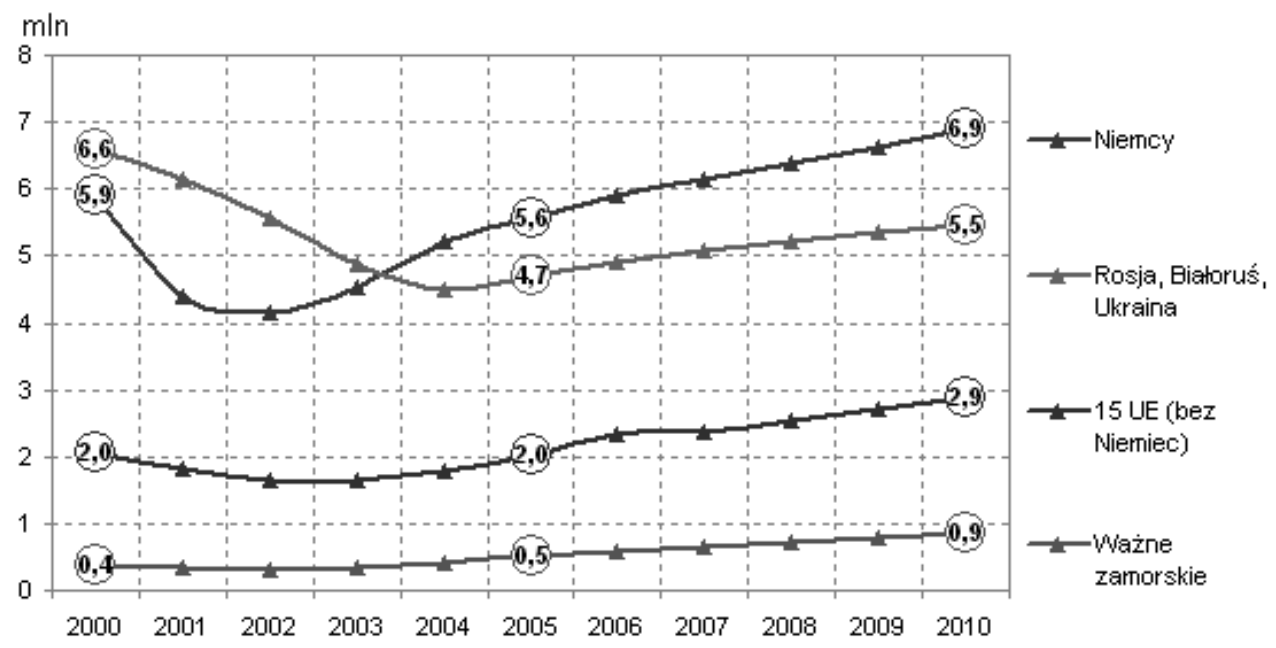

Źródło: Na podstawie oszacowań i prognoz Instytutu Turystyki.

Nie należy zapominać o bardzo ważnym aspekcie odnoszącym się do rynku pracy. W unijnym przemyśle turystycznym, w 2005 roku zatrudnionych było około $9 \mathrm{mln}$ osób (4\% ogółu miejsc pracy). Według realnych prognoz w ciagu 10 lat, tj. do 2013 r. zatrudnienie w szeroko pojmowanej gospodarce turystycznej wzrośnie w tempie znacznie szybszym niż w innych sektorach (także usługowych) gospodarki. Jest to tym bardziej ważne, gdyż liczba pracujących w szeroko rozumianej gospodarce turystycznej Wspólnoty Europejskiej wyniosła w 2005 roku już ponad 24 mln ludzi $(12,1 \%)^{36}$.

Z przyjazdami obcokrajowców nierozerwalnie wiążą się wydatki cudzoziemców, które stanowią wpływy dewizowe dla danego kraju. Wydatki cudzoziemców na turystykę - zgodnie z interpretacją WTO - to całkowite wydatki konsumpcyjne poniesione przez odwiedzającego lub w jego imieniu na jego podróż oraz pobyt w miejscu docelowym. Jeśli chodzi o wpływy dewizowe z turystyki międzynarodowej, ta sama organizacja określa je jako łączne wydatki osób odwiedzających dany kraj, w tym opłaty za transport międzynarodowy na rzecz miejscowych przewoźników oraz wszystkie przedpłaty na dobra i usługi odbierane w kraju docelowym. Zaliczają się nich również przychody od odwiedzających jednodniowych, poza przypadkami, kiedy ich wielkość usprawiedliwia ich wyodrębnienie. 
Nowa jakość polskich granic państwowych w kontekście integrowania się Polski z UE...

Wykres 8. Wpływy dewizowe z turystyki przyjazdowej do Polski w poszczególnych latach (w mld dol.)

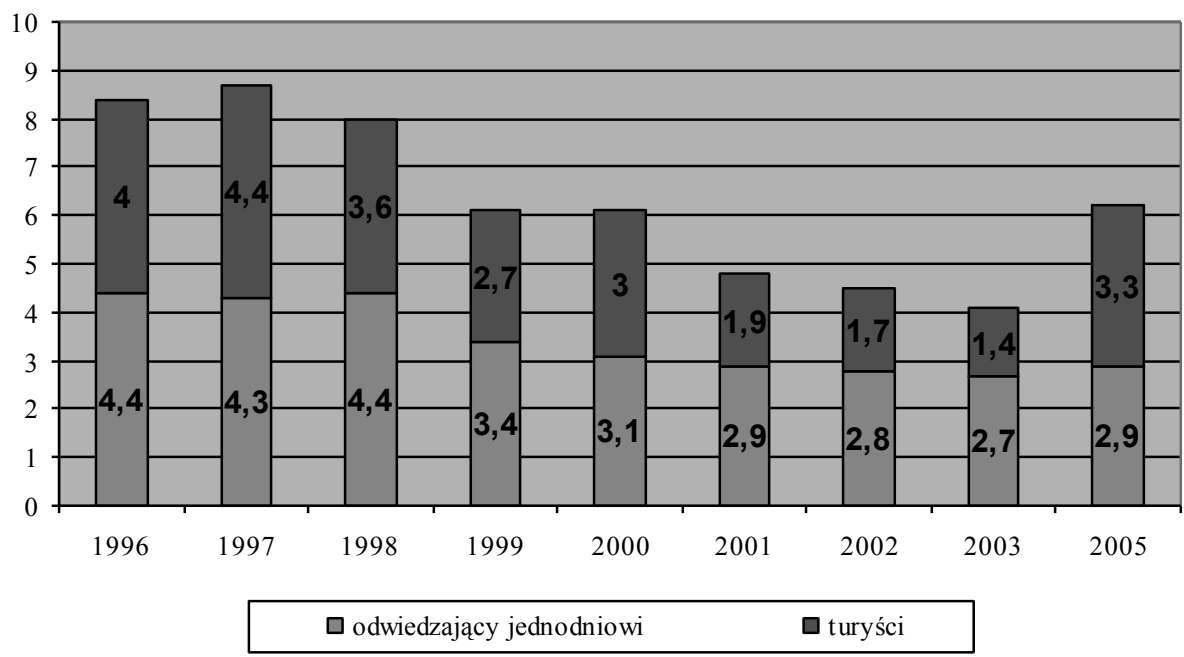

* Szacunki te nie obejmuja wydatków cudzoziemców podejmujacych na terenie Polski pracę zarobkowa (okoto 500 tys. osób).

Źródło: opracowanie własne na podstawie danych Instytutu Turystyki.

Według danych Instytutu Turystyki w Warszawie przychody dewizowe w 2005 roku kształtowały się na poziomie $6230 \mathrm{mln}$ dol., z czego $3330 \mathrm{mln}(\mathrm{tj} .53,5 \%$ ) to wpływy od turystów, pozostała zaś część - od odwiedzających jednodniowych. Wielkość łącznych przychodów z tytułu przyjazdu cudzoziemców wzrósł w stosun-

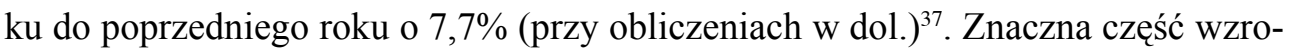
stu przychodów wynika ze zwiększającego się z roku na rok udziału tej ich części, która przepływa przez system bankowy; stąd też rosnący udział wydatków ponoszonych przed podróżą, w kraju stałego zamieszkania, przekazywanych następnie na konta polskich podmiotów gospodarczych. Wzrost przychodów liczonych w dol. to także efekt dużych zmian w kursach walut. Warto przypomnieć, że w 2005 roku nastąpiło obniżenie kursu dolara w stosunku do złotego aż o 11,5\%; analizując wzrost przychodów należy o tym zjawisku pamiętać. W 2005 roku, wg badań Instytutu, przeciętne wydatki turystów poniesione na terenie Polski wyniosły około $156 \mathrm{dol}$. na osobę i blisko 34 dol. dziennie (średnie ważone). Oznacza to niewielki spadek średniej na osobę w stosunku do 2004 roku (o 2,5\%) i utrzymanie średniej na jeden dzień pobytu na tym samym poziomie. Wydatki na osobę według krajów wy- 
niosły od 85 dol. (Rosja) do 327 dol. (kraje zamorskie). Zmiany w relacji do 2004 roku były niejednakowe; warto zwrócić uwagę, że dość znacznie wzrosły przeciętne wydatki turystów z krajów skandynawskich (o 20,4\%), Węgier (o 12,3\%) i wybranych, „ważnych” krajów zamorskich (o ponad 10\%). Istotny jest ponadto dość znaczny wzrost przeciętnych wydatków turystów z Niemiec (o 5,1\%). W odniesieniu do przyjazdów z wielu krajów odnotowano z kolei spadek przeciętnych wydatków na osobę (z Ukrainy o 36,1\%, z Rosji o 19,8\%, z Belgii i Holandii po około $17,3 \%)^{38}$.

Jeśli chodzi o strukturę wydatków według rodzajów, to należy odnotować, że około 36,8\% środków finansowych pozostawionych w Polsce turyści przeznaczają na noclegi, a blisko jedną piątą na wyżywienie $(19,3 \%)$. W porównaniu z rokiem 2004 znaczenie obydwu tych pozycji w łącznym budżecie nieco wzrosło (zwłaszcza w rezultacie wzrostu tej części wydatków, która była przeznaczona na pokrycie kosztów zakwaterowania). Analizując strukturę wydatków w 2005 roku, warto natomiast zwrócić uwagę na wciąż dość duży, lecz malejący udział wydatków na zakupy (zwłaszcza z zamiarem odsprzedaży). Wydatki na zakupy (na własne potrzeby oraz w celu odsprzedania) stanowiły łącznie $22,4 \%$ budżetów turystów wobec $25,7 \%$ w 2004 roku. Podobnie jak w latach poprzednich, stanowily one w 2005 roku bardzo ważną część budżetów osób przyjeżdżających z Ukrainy (66,4\%), Białorusi $(53,1 \%)$, Rosji $(42,5 \%)$ i Litwy $(42,9 \%)$. Również Niemcy przeznaczali dość duże sumy na zakupy na własne potrzeby (ok. 12,9\%) ${ }^{39}$.

Reasumując, można stwierdzić, że turystyka staje się jedną z największych gałęzi światowej gospodarki. Także w Unii Europejskiej (również Polski już jako członka tej społeczności) stanowi ważną i dynamiczną gałąź gospodarki. Ze względu na duży i niedający się łatwo wyeliminować udział pracy ludzkiej sektor ten odgrywa istotną rolę $\mathrm{w}$ dziedzinie zwiększania zatrudnienia i walki z bezrobociem. $\mathrm{Na}$ odnotowanie zasługuje fakt, że w dzisiejszych czasach co dwunaste miejsce pracy na świecie istnieje dzięki turystyce i podróżom. Dlatego też sektor ten jest (powinien być) przedmiotem dużego zainteresowania i niejednokrotnie wsparcia ze strony określonych czynników, m.in. w zakresie stwarzania jak najdogodniejszych warunków przekraczania granic państwowych.

\section{Uwagi końcowe}

1. Poczynając od ostatniej dekady ubiegłego stulecia, wraz z zapoczątkowaniem w Europie Środkowej i Wschodniej procesów transformacji ustrojowej, a potem integracji ekonomicznej, a także w związku z nasilaniem się procesów globali- 
zacji większości przejawów życia społeczno-gospodarczego mamy tu do czynienia z względnie swobodnym przemieszczaniem się osób przez granice państwowe. W latach 90-tych region ten stał się unikalnym obszarem, gdzie granice polityczne stały się względnie otwarte dla tego przemieszczania się. Otwarcie granic wpisało się tym samym niejako zasadniczo w ustanowienie dobrych wielostronnych kontaktów z sąsiadami, prowadzonych przez Polskę i inne kraje tego regionu.

2. Ww. zmiany musiały tym samym wpłynąć na skalę zjawiska przemieszczania się ludzi przez granice państwowe. Powiększyło to także skalę imigracji zza wschodniej granicy Polski i liczby nielegalnie pracujących także w Polsce - ze wszystkimi tego (pozytywnymi i negatywnymi) skutkami.

3. Integrowanie się Polski z UE i konieczność stopniowego wdrażania postanowień schengeńskich przyczyniły się do kształtowania się nowej (dostosowywanej do wymogów unijnych) jakości polskich granic. W UE mamy do czynienia w okresie 2000-2003 ze stopniowym wprowadzaniem ruchu wizowego dla obywateli tzw. państw trzecich. Tym samym również Polska do 1 maja 2004 r. musiała do tych wymogów dostosować się i wprowadzić ruch wizowy i stopniowo dostosowywać swoje regulacje prawne do pełnego (21.12.2007 r.)wdrożenia postanowień schengeńskich.

4. Przeprowadzona w tym opracowaniu dość szczegółowa analiza zagadnień przepływu ludzi przez polsko-rosyjską granicę w latach 2000-2005 pokazała, że po początkowym spadku natężenia tego ruchu osobowego w związku z nowymi wymogami wizowymi szybko następuje jego normalizacja i zbliżanie się do poziomu sprzed 2000 roku.

5. Wizy, jako dość uciążliwa bariera, wprowadzona 1 października 2003 roku także wobec naszych wschodnich sąsiadów, stworzyły tzw. „,nowy reżim graniczny". Spowodowało to określone następstwa w skali i strukturze zagranicznej turystyki przyjazdowej (w tym także obywateli Federacji Rosyjskiej), która jest istotną częścią przyjazdów ogółem cudzoziemców do Polski. Widoczny jest również aspekt ekonomiczny związany ze zmniejszeniem się w analizowanym okresie wpływów z tytułu turystyki zagranicznej. Przyczyny tego stanu rzeczy tkwią w spadku liczby turystów zagranicznych przybywających do Polski zza wschodniej granicy - w tym zwłaszcza z Federacji Rosyjskiej.

6. Dalsze łagodzenie „reżimu wizowego” staje się warunkiem koniecznym powstawania tzw. ,przyjaznej granicy”, a tym samym także eliminacji tutaj wcześniej (w punktach 1-5) podnoszonych mankamentów nowo powstałej sytuacji. Od tego także będzie zależeć proces tworzenia dobrosąsiedzkich stosunków i wzmacniania całokształtu stosunków społeczeństw Polski i Federacji Rosyjskiej. 


\section{НОВОЕ КАЧЕСТВО ПОЛЬСКИХ ГОСУДАРСТВЕННЫХ ГРАНИЦ В КОНТЕКСТЕ ИНТЕГРАЦИИ ПОЛЬШИ С ЕС И ПРОБЛЕМЫ ПЕРЕМЕЩЕНИЯ ЛЮДЕЙ ЧЕРЕЗ ГРАНИЦУ РЕСПУБЛИКИ ПОЛЬША И РОССИЙСКОЙ ФЕДЕРАЦИИ. ИЗБРАННЫЕ ЭКОНОМИКО-ПРАВОВЫЕ АСПЕКТЫ}

В работе затрагиваются проблемы общего движения через польскую восточную границу. Анализируются правовые основы пограничного контроля и обслуживания пассажирского движения. Затрагиваются также вопросы пересечения границы в 2000-2005/2006 годы, т.е. в период так называемого интегрирования Польши с ЕС и введения шенгенских правил. Кроме правового аспекта этих проблем, затронуты также некоторые экономические вопросы, а именно экономические последствия принятых в данной области решений. В первую очередь на основании доступных эмпирических данных проведено исследование влияния рассматриваемого явления на перемену динамики пассажирского движения. Затем предпринимается попытка оценить последствия перемен в международном туризме для польской экономики, в том числе в связи с изменением ситуации на польско-российской границе. 


\section{THE NEW QUALITY OF THE POLISH NATIONAL FRONTIERS IN THE CONTEXT OF POLISH INTEGRATION WITH THE EU AND THE PROBLEMS OF THE MOVEMENT OF PEOPLE ACROSS THE BORDERS OF THE REPUBLIC OF POLAND AND THE RUSSIAN FEDERATION. SELECTED LEGAL AND ECONOMIC ASPECTS}

The present study considers issues surrounding cross-border traffic across the Polish eastern border, with a particular focus on the . Polish-Russian border. The first part of the analysis concerns the legal basis of border controls and services for the movement of people. In addition, issues relating to the permeability of the border mostly during the years 2000-2005/2006, over the so-called period of Polish integration with the EU and the implementation of the provisions of the Treaty of Schengen are highlighted. In addition to the legal aspects of the issues raised, certain economic issues were also considered - the economic repercussions of the adopted measures. In the first instance, the impact of the changes on the dynamics of movement of people was examined, using data from an available empirical base. This was followed by an attempt to estimate the effects on the Polish economy of changes in international tourism, which were also due to the changes affecting the Polish-Russian border.

Key words:

Movement of people, Russia, Poland, Schengen, border control 